Jurnal Ecobisma Vol. 6 No. 1 Jan 2019

\title{
ANALISIS PENGARUH HUMAN CAPITAL TERHADAP KINERJA KARYAWAN PADA PT.MUSTIKA ASAHAN JAYA
}

\section{Zuriani Ritonga}

\author{
Sekolah Tinggi Ilmu Ekonomi Labuhanbatu, Sumatera Utara - Indonesia
}

\begin{abstract}
ABSTRAK
Penelitian ini di lakukan dengan metode analisis kuantitatif dengan populasi adalah karyawan pada PT.MUSTIKA ASAHAN JAYA. Hasil analisis menunjukkan bahwa pengaruh antara human kapital terhadap kinerja karyawan pada PT. Mustika Asahan Jaya dengan hasil regresi Y = 2,203 0,515X 1 . Sedangkan nilai $\mathrm{R}^{2}=63,50 \%$ dan sisanya dipengaruhi variabel lainnya yang tidak diikutkan dalam penelitian ini..
\end{abstract}

Kata kunci: Human capital, Kinerja Karyawan.

\section{Pendahuluan}

Munculnya pandangan bahwa pengetahuan sebagai sumber daya perusahaan yang sangat strategik didasari kenyataan bahwa pengetahuan dapat digunakan untuk mengembangkan daya saing perusahaan karena bernilai langka, sukar ditiru oleh para pesaing dan tidak dapat digantikan oleh jenis sumber daya yang lain. Menurut Mayo (2000) mengukur kinerja perusahaan dari perspektif keuangan sangatlah akurat tetapi sebenarnya yang akan menjadi dasar penggerak nilai dari keuangan tersebut adalah sumber daya manusia (human capital) dengan segala pengetahuan, ide, dan inovasi yang dimilikinya. Selain itu, human capital merupakan inti dari suatu perusahaan. Walaupun sumber daya manusia atau human capital dapat mendorong daya saing perusahaan, namun sayang sekali di banyak perusahaan sumber daya manusia masih jarang mendapat perhatian utama. Banyak para pemimpin perusahaan kurang menyadari bahwa keuntungan yang diperoleh perusahaan sebenarnya berasal dari human capital, hal ini disebabkan aktivitas perusahaan lebih dilihat dari perspektif bisnis semata. Para pemimpin perusahaan tidak melihat perusahaannya sebagai sebuah unit dari aset usahanya yang berisi pengetahuan dan ketrampilan yang unik, atau seperangkat keunikan dari aset usahanya yang dapat membedakan produk atau jasa dari pesaingnya.

Kinerja yang berasal dari kata "kerja" merupakan aktivitas yang dilakukan oleh seseorang atau organisasi dalam menjalankan tugas yang menjadi pekerjaannya. Derajat kompetisi perusahaan atau kinerja perusahaan dicerminkan melalui kinerja individu-individu dalam perusahaan tersebut. Pada akhirnya, penilaian tentang kinerja individu karyawan berperan penting bagi perusahaan untuk membuat program pengembangan SDM secara optimum. Sehingga perusahaan perlu mengetahui faktor-faktor apa saja yang mempengaruhi kinerja. Ada beberapa syarat bagi ukuran kinerja yang baik, antara lain: berkaitan dengan tujuan organisasi, seimbang antara jangka panjang dan jangka pendek, 
mencerminkan aktivitas kunci manajemen memberi efek pada tindakan karyawan, mudah dipahami oleh karyawan, dipergunakan sebagai dasar evaluasi kinerja dan penentuan balas jasa, rasional, obyektif dan dapat diukur, serta dipergunakan secara konsisten dan teratur.

\section{Kinerja karyawan}

Istilah kinerja berasal dari kata Job Performance prestasi kerja atau prestasi sesungguhnya yang dicapai oleh seseorang. Pengertian Kinerja adalah hasil kerja secara kualitas dan kuantitas yang dicapai oleh seorang pegawai dalam melaksanakan tugasnya sesuai dengan tanggung jawab yang diberikan padanya Mangkunegara (2013). Kinerja menurut Fahm (2014) adalah hasil yang diperoleh oleh suatu organisasi baik organisastersebut bersifat profit oriented dan non profit oriented yang dihasilkan selama satu periode waktu. Menurut Simanjuntak (2005) dalam Widodo (2015) Kinerja adalah tingkatan pencapaian hasil atas pelaksanaan tugas tertentu. Simanjuntak juga mengartikan kinerja individu sebagai tangka pencapaian atau hasil kerja seseorang dari sasaran yang harus dilaksanakan dalam kurun waktu tertentu.

Kinerja dapat diartikan penampilan hasil kerja karyawan baik secara kuantitas maupun kualitas. Menurut Marwansyah (2010) kinerja adalah pencapaian atau prestasi seseorang berkenaan dengan tugas-tugas yang dibebankan kepadanya. Sedangkan menurut Kasmir (2016) kinerja merupakan hasil kerja dan perilaku kerja seseorang dalam suatu periode dan biasanya dalam 1 tahun.

Dari beberapa definisi menurut para ahli diatas dapat disimpulkan bahwa kinerja meruapakan hasil kerja yang diperoleh oleh seseorang ataupun sekelompok orang dalam suatu instansi dengan tanggung jawab masing-masing dalam rangka upayapencapaian tujuan instansi sesuai dengan prinsip tertentu. berikut :

Berikut faktor yang mempengaruhi kinerja menurut Mangkunegara (2013) adalah sebagai

C. Faktor Kemampuan, secara psikologis kemampuan pegawai terdiri dari kemampuan potensi (IQ) dan kemampuan realiti (skill). Artinya, pegawai yang memiliki IQ di atas rata-rata (IQ 110-120) dengan pendidikan yang memadai untuk jabatannya dan terampil dalam mengerjakan pekerjaan sehari-hari, maka ia akan lebih mudah mencapai kinerja yang diharapkan. Jadi, jika seorang pemimpin atau karyawan tersebut mempunyai potensi atau keahlian dalam bekerja di suatu organisasi bisa jadi akan meningkatkan kemajuan dari organisasi tersebut.

D. Faktor Motivasi, motivasi terbentuk dari sikap seorang pegawai dalam menghadapi situasi kerja. Motivasi merupakan kondisi yang menggerakkan diri pegawai yang terarah untuk mencapai tujuan organisasi. 


\section{Human capital}

Human capital secara bahasa tersusun atas dua kata dasar yaitu manusia dan kapital (modal). Kapital diartikan sebagai faktor produksi yang digunakan untuk membuat suatu barang atau jasa tanpa mengonsumsinyaselama proses produksi. Berdasarkan definisi kapital tersebut, manusiadalam human capital merupakan suatu bentuk modal seperti halnya mesindan teknologi. Manusia juga memiliki peran atau tanggung jawab dalamsegala aktifitas ekonomi, seperti produksi, konsumsi, dan transaksi.

Intellectual capital merupakan aset tidak berwujud (intangible asset) yang dimiliki oleh perusahaan, dan merupakan salah satu aset terbesar yang dimiliki oleh perusahaan. Human capital diartikan sebagai manusia itu sendiri yang secara personal dipinjamkan kepada perusahaan dengan kapabilitas individunya, komitmen, pengetahuan dan pengalaman pribadi. Walaupun tidak semata-mata dilihat dari individual tapi sebagai tim kerja yang memiliki hubungan pribadi baik di dalam maupun diluar perusahaan.

Seiring berkembangnya teori ini, konsep human capital dapatdidefinisikan menjadi tiga. Konsep pertama adalah human capital sebagaiaspek individual. Konsep ini menyatakan bahwa modal manusia merupakan suatu kemampuan yang ada pada diri manusia, seperti pengetahuan dan keterampilan. Hal ini diperjelas oleh Rastogi (2002) yang menyatakan bahwa human capital merupakan pengetahuan, kompetensi, sikap, kesehatan, dan sifat yang dimiliki oleh manusia. Konsep kedua menyatakan bahwa human capital merupakanpengetahuan dan keterampilan yang didapatkan melalui berbagai aktifitaspendidikan seperti sekolah, kursus, dan pelatihan. Konsep utama model iniadalah bahwa human capital merupakan sesuatu yang didapatkan melaluiakumulasi suatu proses tertentu (Alan dkk, 2008). Konsep ini menganggaphuman capital tidak berasal dari pengalaman manusia.

Konsep ketiga memandang human capital melalui perspektif orientasi produksi. Romer (1999) menyatakan bahwa human capital merupakan sumber mendasar dari produktifitas ekonomi. Human capital juga merupakan sebuah investasi yang dilakukan manusia untuk meningkatkan produktifitasnya (Rosen, 1999). Frank \& Bemanke (2007) berpendapat bahwa human capital adalah perpaduan antara pendidikan, pengalaman, pelatihan, keterampilan, kebiasaan, kesehatan, energy dan inisiatif yang memengaruhi produktifitas manusia.

\section{Metode Analisis Data}

Metode analisis yang digunakan dalam penelitian ini adalah dengan Metode Ordinary Least Square (OLS). Hal ini digunakan untuk melihat elastistas variabel independen terhadap variabel dependen penelitian ini dengan menggunakan alat analisis untuk mengolah data adalah dengan menggunakan program SPSS versi 20.0 


\section{Hasil}

\section{Analisis Regresi Linier Berganda}

Tabel 1

Analisis Regresi Linier sederhana

\section{Coefficients $^{a}$}

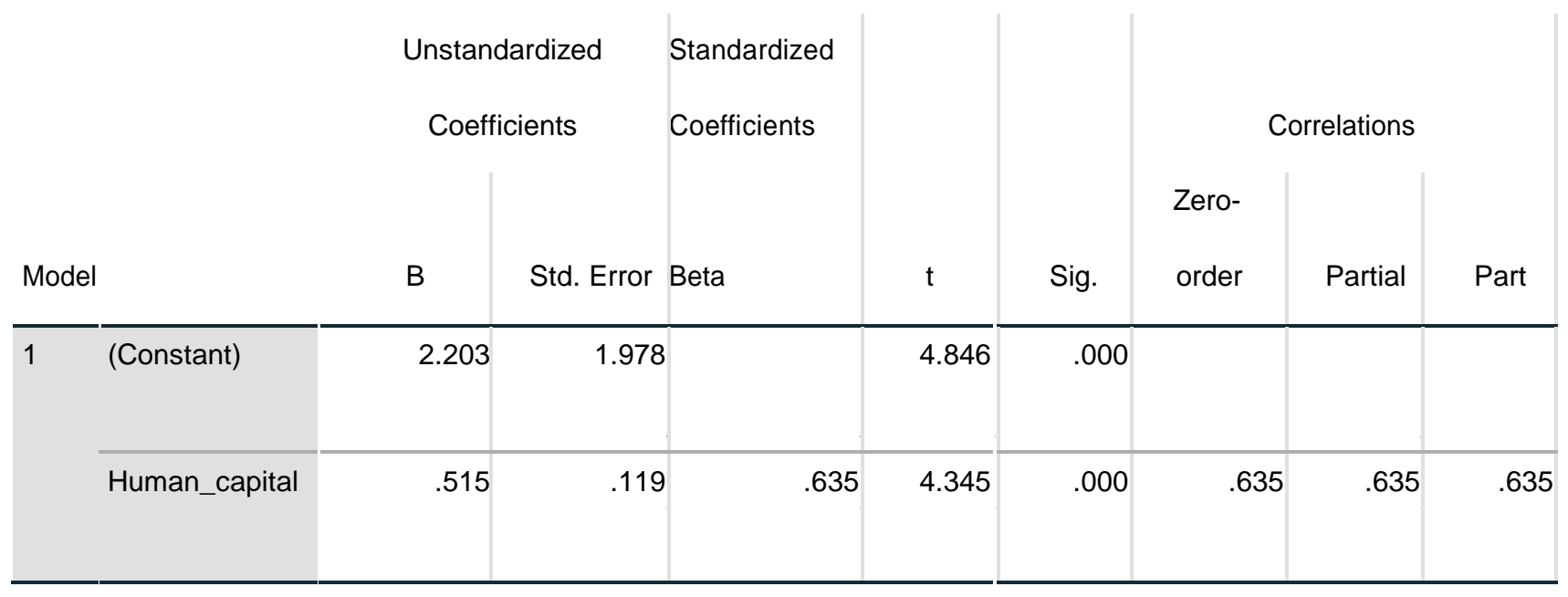

a. Dependent Variable: Kinerja

Sumber: Out put SPSS, data diolah (2019 
Dari hasil perhitungan diatas dapat dibuat sebuah model persamaan regresi linier sederhana, yaitu sebagai berikut : $\mathrm{Y}=2,203+0,515 \mathrm{X}_{1}$

Tabel 2

\title{
Koefisien Determinasi $\left(\mathbf{R}^{2}\right)$
}

\section{Model Summary}

\begin{tabular}{|c|c|c|c|c|c|c|c|c|c|}
\hline \multirow[b]{2}{*}{ Mode } & & & \multirow[b]{2}{*}{ Adjusted R } & Std. Error & \multicolumn{5}{|c|}{ Change Statistics } \\
\hline & & $\mathrm{R}$ & & of the & R Square & $\mathrm{F}$ & & & Sig. $F$ \\
\hline I & $\mathrm{R}$ & Square & Square & Estimate & Change & Change & df1 & $\mathrm{df} 2$ & Change \\
\hline 1 & $.635^{\mathrm{a}}$ & .403 & .381 & 1.764 & .403 & 18.883 & 1 & 2 & .000 \\
\hline
\end{tabular}

\author{
a. Predictors: (Constant), Human_capital \\ b. Dependent Variable: Kinerja
}

Berdasarkan hasil SPSS didapat nilai koefisien determinasi sebesar 0,635 Artinya $63,50 \%$ variabel human capital mempengaruhi kinerja dan sisanya sebesar 36,50\% dijelaskan oleh variabel lain

\section{Pembahasan}

Dari hasil penelitian yang telah dilakukan penulis maka diperoleh kevalitan data kuesioner dan reliabilitas seluruh instrumennya. Nilai uji validitas diperoleh hasil thitung $>$ ttabel. Untuk reliabilitas instrument, kuesioner dinyatakan dapat digunakan untuk pengukuran dalam rangka pengumpulan data dikarenakan rhitung $>$ rtabel dan keputusan dinyatakan reliabel dan layak digunakan sebagai alat pengukuran dalam penelitian ini.

Hasil persamaan regresi diperoleh $\mathrm{Y}=2,203+0,515 \mathrm{X}_{1}$. Hasil koefisien determinasi diperoleh 0,635 Artinya 63,50\% variabel terikat dijelaskan oleh variabel bebas dan sisanya dijelaskan oleh variabel lain diluar variabel yang digunakan.

\section{Kesimpulan}

Human capital theory menggunakan konsep bahwa modal utama manusia adalah pendidikan, keterampilan, dan kesehatan. Human investment theory menggunakan konsep 
mengorbankan sesuatu saat ini demi keuntungan lebih di masa depan. Secara parsial human capital memiliki pengaruh positif terhadap kinerja perusahan.

\section{Referensi}

AA. Anwar Prabu Mangkunegara, 2013, Manajemen Sumber Daya Manusia Perusahaan, Remaja Rosdakarya, Bandung

Alan, K. M. A., Altman, Y., \& Roussel, J. 2008. Employee Training Needs and Perceived Value of Training in the Pearl River Delta of China: AHuman Capital Development Approach. Journal of European Industrial Training, 32(1), 19-31.

Eko, Widodo Suparno. 2015. Manajemen Pengembangan Sumber Daya Manusia.Yogyakarta: PUSTAKA PELAJAR

Frank, R. H., \& Bernanke, B. S. 2007. Principles of Microeconomics (3rd ed.). New York: McGraw-Hill/Irwin.

Fahmi, Irham. 2014. Pengantar Manajemen Keuangan. Bandung: Alfabeta

Kasmir. 2016. Dasar-Dasar manajemen (Teori dan Praktik). Jakarta: PT raja Grafindo Persada Mayo, A., 2000. "The Role of Employee Development in he Growth of Intellectual Capital".

Personel Review, Vol. 29 No.4, hal. 521-533

Marwansyah. 2010. Manajemen sumber daya manusia. Alfabeta:Bandung.

Rastogi, P. N. 2002. Knowledge Management and Intellectual Capital as a Paradigm of Value Creation. Human Systems Management, 21(4).229-240.

Romer, P. M. 1990. Endogenous Technological Change. Journal of Political Economy, 98(5), 71- 102 .

Rosen, H. S. 1999. Public Finance. New York: McGraw-Hill. 